\title{
BUKU AJAR SEBAGAI SALAH SATU ALTERNATIF PERCEPATAN STUDI MAHASISWA PROGRAM STUDI DESAIN KOMUNIKASI VISUAL
}

\author{
Pujiyanto \\ Program Studi Desain Komunikasi Visual Jurusan Seni dan Desain \\ Fakultas Sastra Universitas Negeri Malang \\ pujiyanto.msn@gmail.com
}

\begin{abstract}
Abstrak
Penelitian ini dilatarbelakangi oleh kondisi sebenarnya yang terjadi pada Program Studi Desain Komunikasi Visual, yaitu mahasiswa lulus S1 dilakukan tercepat 10 semester, paling lama hingga perpanjangan studi mencapai 18 semester. Lamanya mahasiswa dalam studi tersebut salah satunya disebabkan oleh pemrograman matakuliah wajib yang sifatnya persyarat, yaitu Desain Komunikasi Visual I s.d V. Desain penelitian ini adalah penelitian deskriptif dan kajian dilakukan secara kualitatif dengan subjek sample penelitian adalah dokumen, dosen, dan mahasiswa Program Studi Desain Komunikasi Visual Univeritas Negeri Malang, Universitas Sebelas Maret Surakarta, dan Institut Seni Indonesia Yogyakarta. Data penelitiannya berupa hasil observasi, wawancara, dan dokumentasi. Dalam penelitian kualitatif ini peran peneliti dalam melakukan penelitian adalah sebagai pengamat bersifat partisipatif untuk menjaring data-data yang bersifat verbal. Adapun analisis data, menggunakan pendekatan kualitatif dengan teknik triagulasi. Data diperoleh di tiga perguruan tinggi hampir sama yaitu mahasiswa kurang adanya motivasi, kurang lancar, dan tidak tepat waktu dalam studi di Program Studi Desain Komunikasi Visual. Agar perkuliahan tersebut berjalan dengan lancar dan tepat waktu maka diperlukan media pembelajaran berupa buku ajar pada matakuliah Desain Komunikasi Visual I hingga Desain Komunikasi Visual V.
\end{abstract}

Kata kunci: buku ajar, percepatan studi, desain komunikasi visual

\section{PENDAHULUAN}

Desain merupakan bidang ketrampilan, pengetahuan dan pengalaman manusia yang mencerminkan keterkaitannya dengan apresiasi dan adaptasi lingkungannya ditinjau dari kebutuhan-kebutuhan kerohanian dan keberadaanya. Secara khusus, desain dikaitkan dengan konfigurasi, komposisi, arti, nilai dan tujuan dari fenomena buatan manusia. Komunikasi visual, merupakan media yang mempergunakan mata sebagai alat penglihatan. Komunikasi visual adalah komunikasi menggumakan bahasa visual, di mana unsur dasar bahasa visual sebagai kekuatan utama dalam penyampaian pesan, serta segala sesuatu yang dapat dililhat dan dapat dipakai untuk menyampaikan arti, makna, atau pesan (Kusrianto, 2007: 10).

Sandra Moriarty, Nancy Mitchell, dan William Wells (2011: 508-509), agar desain komunikasi visual mempunyai efek yang baik, maka harus: (1) menarik perehatian, umumnya visual lebih mampu menarik perhatian dan mempertahankan perhatian dari pada kata-kata, (2) melekat dalam memori, visual bertahan di ingatan karena orang biasanya ingat pesan atau gambar sebagai fragmen visual, (3) memperkuat keyakinan, visual menunjukkan dan menambah kredibilitas, (4) menceritakan kisah menarik, penceritaan visual lebih membangkitkan dan mampu mempertahankan perhatian, (5) 
mengkomunikasikan dengan cepat, gambar member kabar lebih cepat daripada katakata, dan (6) asosiasi, untuk menonjolkan produk sring diasosiasi visual yang merepresentasikan gaya hidup atau tipe pengguna.

Yongky Safanayong (2006: 3), desain komunikasi visual memiliki fungsi sosial, fungsi fisik, dan fungsi pribadi, seperti: (1) untuk memberitahu atau memberi informasi (to inform), mencakup; menjelaskan, menerangkan dan mengenalkan, (2) untuk memberi penerangan (to enlighten), mencakup; membuka pikiran dan menguraikan, (3) untuk membujuk (to persuade), mencakup, menganjurkan (umumnya dalam media promosi), komponen- komponennya termasuk kepercayaan, logika dan daya tarik, dan (4) untuk melindungi (to protect), fungsi khusus untuk desain kemasan dan kantong belanja.

Adi Kusrianto (2007: 2), menyatakan desain komunikasi visual bertujuan mempelejari konsep-konsep komunikasi serta ungkapan kreatif melalui berbagai media untuk menyampaikan pesan dan gagasan secara visual dengan mengelola elemen-elemen grafis yang berupa bentuk dan gambar, tatanan huruf, serta komposisi warna serta layout (tata letak atau perwajahan). Dalam hal ini, gagasan bisa diterima oleh orang atau kelompok yang menjadi sasaran penerima pesan.

Diperjelas oleh Sumbo Tinarbuko (2007: 27-28) dalam kumpulan tulisan dalam bentuk buku "Irama Visual" menyatakan bahwa desain komunikasi visual merupakan ilmu yang mempelajari konsep komunikasi dan ungkapan daya kreatif yang diaplikasikan dalam berbagai media komunikasi visual dengan mengolah elemen desain grafis yang terdiri dari gambar (ilustrasi), huruf, warna, komposisi dan layout. Semuanya itu dilakukan guna menyampaikan pesan secara visual, audio, dan audio visual kepada target sasaran yang dituju.

Desain komunikasi visual dalam perguruan tinggi di bagi menjadi 5 matakuliah, yaitu Desain Komunikasi Visual I, II, III, IV, dan V. Matakuliah tersebut wajib diikuti semua mahasiswa Program Studi Desain Komunikasi Visual dengan aturan berjenjang dan bersyarat. Matakuliah berjenjang adalah matakuliah yang mempunyai urutan pemrograman dari yang dasar hingga yang lebih sulit dan berat. Adapun matakuiah bersyarat adalah matakuliah yang diprasyarati pada matakuliah pada semester sebelumnya atau matakuliah yang mendasari pada matakuliah yang adak diambil/diprogram. Bila mahasiswa belum memprogram matakuliah yang mendasarinya, berarti mahasiswa tidak boleh memprogram/mengambil pada matakuliah yang dikeluarkan pada semester tententu. Sebagai contoh matakuliah di Universitas Negeri Malang, VIS 419 Desain Komunikasi Visual II, 6 sks/6 js, prasyarat VIS 418, VIS 420 Desain Komunikasi Visual III, 6 sks/6 js, prasyarat VIS 419, VIS 421 Desain Komunikasi Visual IV, 6 sks/6 js, prasyarat VIS 420, VIS 422 Desain Komunikasi Visual V, 6 sks/6 js, prasyarat VIS 421.

Mahasiswa dalam melaksanakan studinya tidak semulus dengan yang kita bayangkan, karena ada hambatan-hambatan dalam pemikirannya. Menurut George C. Beakley (1974: 369-370) hambatan tersebut antara lain; a). Hambatan dalam pengalaman dan 
persepsi, yaitu hambatan seseorang dalam menanggapi masalah yang didasari oleh pengalamannya. Biasanya seseorang mengandalkan pendidikannya untuk mengatasi permasalahannya, sehingga ia terikat oleh apa yang dipelajari di bangku kuliah, b). Hambatan mental, yaitu hambatan yang mempengaruhi dalam kegiatan kreatifitas, seperti strees yang diakibatkan oleh nkritikan yang disampaikan kepadanya. Kritikan yang tajam mengakibatkan pikiran yang berkepanjangan sehingga konsentrasi berkreasi berkurang, c). Hambatan sosial budaya, yaitu hambatan dalam kehidupan bermasyarakat yang mengakibatkan terhambatnya kreativitas berpikir. Hambatan ini timbul karena adanya perbedaan status tingkat pendidikan atau pengetahuan dan kesalah pahaman budaya yang ada pada seseorang.

Salah satu cara untuk mengatasi masalah hambatan dalam studi mahasiswa desain komunikasi visual adalah dengan tersedianya media pembelajaran. Media adalah perantara atau pengantar pesan dari pengirim kepada penerima pesan. Bila dipahami secara garis besar adalah manusia, materi, atau kejadian yang membangun kondisi yang membuat mahasiswa mampu memperoleh pengetahuan, keterampilan, atau sikap. Dalam pengertian ini, guru/dosen, buku teks, dan lingkungan sekolah merupakan media (Arsyat, 2007:3).

Fungsi media pembelajaran dalam proses belajar mengajar menurut Derek Rowntree (dalam Rohani, 1997:7), adalah 1) Membangkitkan motivasi belajar, 2) Mengulang apa yang telah dipelajari, 3) Menyediakan stimulus belajar, 4) Mengaktifkan respon peserta didik, 5) Memberikan balikan dengan segera, 6) Menggalakan latihan yang serasi. Jadi, media adalah segala sesuatu yang dapat diindra yang berfungsi sebagai perantara/sarana/alat untuk proses komunikasi dalam proses belajar mengajar.

Meskipun begitu, Perguruan Tinggi dalam program pendidikannya selalu dituntut kemajuan dalam pengajarannya, sehingga melahirkan lulusan yang bagus. Untuk menghasilkan out-put yang bagus dapat dilakukan melalui input (masuknya mahasiswa) atau memberikan materi dalam pendidikan yang baik sehingga dapat menghasilkan kualitas yang baik dan siap dibutuhkan di masyarakat. Pemberian pendidikan yang baik, tidak hanya penyediaan tempat dan peralatan dalam proses mengajar tetapi juga didikung dengan kualitas sumber daya manusia pendidikan dan sumber/media pembelajaran. Belum adanya buku ajar sebagai sumber/media pembelajaran pada matakuliah keahlian sangat sulit didapat di toko-toko buku, seandainyapun ada tentunya tidak bisa mewadahi semua materi pada matakuliah Desain Komunikasi Visual.

Sebagian besar mahasiswa agak kerepotan bila memprogram matakuliah tersebut di atas, karena informasi yang diberikan dosen pengajar kadang terbatas yang kurang bisa mewadahi semua tugas yang diberikan, seperti ilmu pengetahuan dan contoh karya serta aplikasinya, sehingga mahasiswa yang tidak mandiri bisa ketinggalan yang akhirnya tidak lulus. Kondisi ini tidak akan terjadi bila ada rujuan dalam mendampingi mahasiswa dalam belajar, yaitu buku ajar khusus yang bisa menamping keilmuan 
matakuliah Desain Komunikasi Visual I, II, III, IV, dan V. Bila ini tidak dilakukan, maka percepatan studi Program Studi Desain Komunikasi Visual sangat sulit terwujud.

Dalam kondisi sekarang ini, mahasiswa Program Studi Desain Komunikasi Visual sebagian besar dalam lulusannya lebih dari 10 semester. Kondisi ini sangatlah memprihatinkan. Bagaimana seandainya waktu yang ditentukan sudah habis, padahal mahasiswa harus mengikuti peraturan yang telah ditentukan di kampusnya. Hal inilah yang perlu diselesaikan, salah satunya belum adanya buku perkuliahan yang bisa mewadai matakuliah bersyarat "Desain Komunikasi Visual I s.d V".

\section{METODE PENELITIAN}

Penelitian ini adalah penelitian deskriptif dan kajian dilakukan secara kualitatif. Artinya bahwa penelitian ini bukan berupa data yang bersifat numeris melainkan menggunakan prosedur penelitian yang menghasilkan data deskriptif berupa gambar, kata-kata, baik lisan maupun tulisan serta perilaku orang yang diamati. Pertimbangan penggunaan desain ini adalah: (1) sumber data bersifat langsung dan alami sehingga tidak memungkinkan untuk melakukan manipulasi data; (2) instrument pokok penelitian adalah peneliti sendiri; (3) pengumpulan data menggunakan wawancara dan dokumentasi; (4) analisis data dilakukan secara deduktif .

Dalam penelitian ini menggunakan subjek sampel penelitian adalah dosen dan mahasiswa Program Studi Desain Komunikasi Visual Univeritas Negeri Malang, Universitas Sebelas Maret Surakarta, dan Institut Seni Indonesia Yogyakarta. Data penelitian ini berupa hasil wawancara dan dokumentasi. Data penelitian juga berkaitan erat dengan: 1) Deskripsi matakuliah, 2) Rencana Pelaksanaan Pembelajaran (RPP) atau Rencana Perkuliahan Semester (RPS), 3) Silabus, 4) Jurnal perkuliahan yang berhubungan dengan kehadiran dosen, 5) Kurikulum DKV, 6) Nilai matakuliah Desain Komunikasi Visual I, II, III, IV, dan V di Univeritas Negeri Malang, Universitas Sebelas Maret Surakarta, dan Institut Seni Indonesia Yogyakarta. Semua data ini sebagai masukan atau acuan untuk pembuatan buku ajar.

Teknik pengumpulan data dilakukan dengan menggunakan teknik wawancara, dan dokumentasi. Wawancara dilakukan secara struktural bebas terpimpin, maksudnya dalam wawancara menggunakan instrumen berupa pertanyaan, namun informan menjawab dengan bebas namun terarah. Informan dalam wawancara adalah para dosen pengajar matakuliah besyarat Desain Komunikasi Visual. Adapun informan dari para mahasiswa, yaitu mereka yang pernah memprogram matakuliah bersyarat Desain Komunikasi Visual pada semester III hingga yag belum lulus. Wawancara dilaksanakan untuk menjaring data sebanyak-banyaknya untuk memperoleh temuan-temuan selama penelitian.

Data dokumentasi dikaji guna mendukung fakta yang ada di lapangan dengan bersumber pada nilai matakuliah bersyarat Desain Komunikasi Visual I, II, III, IV, dan V, serta elemen pendukung akademik pada Program Studi Desain Komunikasi Visual Univeritas Negeri Malang, Universitas Sebelas Maret Surakarta, dan Institut Seni 
Indonesia Yogyakarta. Dalam penelitian kualitatif, peran peneliti dalam melakukan enelitian adalah sebagai pengamat bersifat partisipatif untuk menjaring data-data baik yang bersifat verbal maupun visual. Di samping observasi juga menggunakn instrument wawancara untuk menggali pengalaman atau kesan-kesan selama pelaksanaan belajar pembelajaran bagi dosen pengajar maupun mahasiswa.

Data yang telah diproses dianalisis dengan menggunakan pendekatan kualitatif dengan teknik triagulasi. Dalam penelitian ini dilakukan adaptasi dan pemaduan seperlunya dan teknik-teknik analisis ini digunakan untuk menganalisi data. Penggunaan teknik analisis tersebut meliputi langkah-langkah sebagai berikut: (1) penelaahan dan reduksi data; (2) pengidentifikasian dan sajian data; (3) pengkategorian dan pengolahan data; (4) penarikan kesimpulan. Kesemuannya ini diarahkan ke dalam satu tujuan pembuatan/pengadaan buku ajar matakuliah bersyarat Desain Komunikasi Visual.

\section{HASIL}

Pengumpulan data dijaring melalui wawancara dengan mahasiswa, pejabat Jurusan/Kaprodi, dosen pengampu, dan data yang kumpulkan dari data dokumentasi yang ada di Fakultas atau Jurusan/Prodi Desain Komunikasi Visual

\section{Deskripsi Matakuliah Desain Komunikasi Visual}

Data dokumentasi di Universitas Negeri Malang, Universitas Sebelas Maret Surakarta, dan Insitut Seni Indonesia Yogyakarta, dijelaskan bahwa Deskripsi matakuliah Desain Komunikasi Visual dalah sebagai berikut: (1) Desain Komunikasi Visual I, yaitu menanamkan pengetahuan tentang bahasa visual atau bahasa gambar sebagai media komunikasi yang meliputi ikonigrafi, indexical, dan sign system, serta membentuk keterampilan dalam pengerjaan kasus-kasus desain secara riel sehingga dihasilkan karya desain kreatif yang berkonsep. (2) Desain Komunikasi Visual II, yaitu mengembangkan wawasan tentang proses kreatif bahasa rupa visuality system sebagai rancangan kampanye promosi suatu produk ke dalam karya visual cetak / printed matrial dengan melakukan riset dan penentuan konsep secara terpadu dan berkesinambungan. (3) Desain Komunikasi Visual III, yaitu mampu membuat konsep dalam berbagai media dan kreatifitas beserta pengolahan dan pengembangannya yang disesuaikan dengan karakteristik produk/jasa, media, serta tekik penyampaian bahasa visual-verbal ke dalam isi pesan kepada kalayak sasaran. (4) Desain Komunikasi Visual IV, yaitu mampu membuat konsep visual branding secara terpadu yang meliputi konsep dan analisis posisioning, perencanaan kreatif, strategi pemasaran, strategi media produksi dan distribusi, serta estimasi biaya untuk dipergunakan dalam perancangan satu paket, dan (5) Desain Komunikasi Visual V, yaitu mempelajari tentang proyek desain mulai pemecahan masalah komunikasi visual secara menyeluruh, utuh dan terpadu, mulai dari awal permasalahan sampai pemecahannya yang didukung oleh berbagai disiplin ilmu terkait; serta meningkatkan kemampuan mengaplikasikan dalam berbagai media. 


\section{Pendapat Mahasiswa yang Mengambil Matakuliah Desain Komunikasi Visual}

Dari tiga perguruan tinggi, yaitu Univeritas Negeri Malang, Universitas Sebelas Maret Surakarta, dan Institut Seni Indonesia Yogyakarta sebagai sampel pengumpulan data. Di peroleh data bahwa mahasiswa A1, menyatakan bahwa dosen pada awal semester memberikan RPP/RPS sekaligus menerangkan materi apa saja yang akan diberikan selama satu semester, serta hak dan kewajiban mahasiswa dalam mengikuti matakuliah Deskomvis. Mahasiswa A2, menyatakan bahwa pada awal semester masih adanya koordinasi dan kontrak/perjanjian antara mahasiswa dengan dosen terhadap materi yang akan disampaikan semester berjalan ke depan, baru pertemuan kedua RPP/RPS diberikan kepada mahasiswa yang memprogram Deskomvis. Mahasiswa lain di perguruan tinggi lain B1, menyatakan bahwa RPP/RPS hanya sisampaikan saja, print out nya dibawa dosen pengampu matakuliah Deskomvis. Mahasiswa B2 menyatakan bahwa RPP/RPS disampaikan secara lesan (tidak tertulis) oleh dosen pengampu matakuliah Deskomvis, khususnya menerangkan tugas yang harus dikerjakan oleh mahasiswa. Lain halnya di perguruan C, bahwa mahasiswa C1 menyatakan tidak ada RPP/RPS Dosen hanya menjelaskan pada pertemuan pertama, apa saja yang akan dikerjakan mahasiswa. Dosen hanya memberi contoh-contoh tugas yang akan dikerjakan. Mahasiswa menyatakan, pada pertemuan awal, dosen menjelaskan rencana perkuliahan selama semester serta tugas-tugasnya yang harus dikerjakan. Penjelasan ini disampaikan secara lesan.

Apakah mahasiswa sudah mengetahui isi materi matakuliah Desain Komunikasi Visual?. Jawaban mahasiswa A1, bahwa secara garis besar sudah, seperti yang terlihat pada RPP/RPS yang telah saya terima, namun secara rinci belum karena tiap semester dosen memberikan materi sesuai tema pada semester tertentu (tiap semester tema tidak sama). Mahasiswa A2 sudah mengetahui seperti yang dijelaskan pada awal semester, hanya contohnya tugas yang diharapkan dosen itu seperti apa. Berbeda dengan mahasiswa B1, menyatakan hanya sedikit yang didapat, agar lebih jelas mahasiswa tersebut tanya pada kakak kelas yang sudah menempuh matakuliah Deskomvis. Mahasiswa B2 merasa belum jelas, karena dosennya tim. Kadang dosen yang satu memberi penjelasan begini, sedangkan dosen lain menjelaskan begitu, sehingga mahasiswa tersebut bertanya pada kakak kelas atau melihat tugas-tugas yang dibuat kakak kelas tersebut. Mahasiswa C1 merasa sudah jelas, karena hadir pada pertemuan pertama. Pada pertemuan itulah dosen menjelaskan tentang matakuliah Deskomvis, dan mahasiswa C2 merasa belum tahu, maka mahasiswa ini harus hadir sesuai jadwal perkuliahan agar mendapat informasi dari dosen pengampu atau teman yang memprogram Deskomvis.

Kehadiran dosen dalam mengajar matakuliah Desain Komunikasi Visual menjadi catatan tersendiri pada mahasiswa. Sebagai contoh mahasiswa A1 menyatakan baik, hanya kesibukan dosen yang luar biasa sehingga mengurangi kehadirannya dalam mengajar, maka dosen sering mengadakan konsultasi tugas di luar jam perkuliahan. Mahasiswa A2 menyatakan bahwa kehadiran dosen rata-rata 14 kali pertemuan, itupun tidak semua waktu jam perkuliahan tidah dipergunakan dengan baik, rata-rata 6 jam digunakan 4 jam pertemuan. Berbeda dengan mahasiswa B1 yang menyatakan 
jarang ada, karena kesibukan mengajar di luar kampus. Seandainyapun ada mengajaranya hanya dituntut pada karya akhir semester. Mahasiswa B2, menyatakan rata-rata dosen dalam mengajar hanya 8-10 kali pertemuan, tidak ada jam pengganti, dan ahasiswa dianjurkan mandiri belajar. Mahasiswa C1 menilai bagus karena kehadiran dosen rata-rata 12 kali pertemuan, meskipun dosen banyak kegiatan di luar kampus, mahasiswa C2 menyatakan kehadiran dosen baik, hanya tidak sampai penuh bila mengajar. Tiap hadir selalu menannyakan target tugas matakuliah.

Apakah ada kesulitan dalam mengikuti matakuliah Desain Komunikasi Visual?. Mahasiswa A1 menjawab adanya sedikit kesulitan, karena temanya selalu berubah sehingga arus membuat sesuatu yang baru. Mahasiswa A2 tidak merasas kesulitan, karena mahasiswa ini selalu proaktif kepada dosen pengajar Deskomvis. Mahasiswa B1 merasa binggung, karena dosen kadang sulit dicari untuk konsultasi, dan mahasiswa B2 tampaknya tidak ada kesulitan, karena ia selalu menanyakan kepada kakak kelas yang sudah lulus matakuliah yang diambil sebelumnya. Mahasiswa C1 merasa tidak banyak kesulitan, karena dosen hadir dan sangat membantu dalam pembimbingan. Mahasiswa C2 berjalan lancar- lancar saja karena dosen sering ada meskipun waktu dalam mengajar sangat sedikit, tetapi mahasiswa selalu aktif kerja di kampus. Di Yogyakarta sangat membantu dalam menggali ide karena banyak contoh karya Deskomvis.

Apakah dosen memberikan hand out atau buku ajar?. Mahasiswa A1 menyatakan "ya", ada meskipun tidak secara detail tentang matakuliah yang diajarkan. Mahasiswa A2, menyatakan bukan hand out, tetapi materi pengajaran berupa media interaktif pada materi awal perkuliahan dan beberapa materi penunjang lainnya. Mahasiswa B1 menyatakan tidak ada, materi lesan dari dosen selalu ia catat, dan mahasiswa B2 mencari sendiri, meskipun di perpustakaan Jurusan belum ada. Mahasiswa C1, menyatakan bukan hand out tetapi contoh karya/tugas mahasiswa yang didokumentasi dosen pengajar Deskomvis, dan mahasiswa C2 menyatakan tidak ada, tetapi buku tentang Deskomvis yang ditulis oleh dosen-dosen pengajaranya.

Tanggapan mahasiswa bila materi Deskomvis dibuatkan buku ajar sangatsenang dan setuju. Mahasiswa A1 menyatakan setuju, karena bisa membantu kelancaran perkuliahan Deskomvis, dan mahasiswa A2 menyatakan bagus sekali, terutama contoh-contoh karya pada matakuliah Deskomvis. Mahasiswa B1, menyatakan sangat senang, sehingga saya tidak kebingungan dalam mengerjakan tugas Deskomvis, dan mahasiswa B2, menyatakan sangat membantu dalam perkuliahan, karena saat ini belum ada materi khusus tentang Deskomvis. Begitu juga mahasiswa C1 menyatakan ide yang bagus, sehingga ia tidak harus membaca banyak buku, yang berarti biaya lebih ringan, dan mahasiswa C2 menyatakan setuju, tetapi dalam buku tersebut tidak sekedar terori, tetapi harus diberikan contoh-contoh karya Deskomvis yang sesuai dengan tugas yang diberikan dosen. 


\section{Kehadiran Dosen dalam Mengajar Matakuliah Desain Komunikasi Visual}

Kehadiran dosen bisa dilihat melalui absen/jurnal perkuliahan matakuliah Desain Komunikasi Visual dalam satu semester. Data ini sangat sulit diperoleh karena absen/jurnal sering dibawa oleh dosen pengampu matakuliah. Data yang bisa dideteksi antara lain: (1) Pada kampus A, waktu dalam mengajar Desain Komunikasi Visual kurang tepat waktu dalam jam pertemuan sesuai dengan Rencana Pelaksanaan Pembelajaran (RPP) atau Rencana Perkuliahan Semester (RPS). Ketidak hadiran dosen disebabkan ada tugas lembaga, namun dosen yang bersangkutan berusaha mengganti jam pertemuan di hari lain. Bila diperhatikan, kehadiran dosen dalam mengajar ratarata mencapai 14 pertemuan. (2) Dosen pada kampus B dalam mengajar sebagian masih seenaknya sendiri, hal ini terbukti data di jurnal mengajar tidak sama dengan Rencana Pelaksanaan Pembelajaran (RPP) atau Rencana Perkuliahan Semester (RPS) yang dibuat Jurusan. Kurangnya teraturnya dosen mengajar ini dikarena banyak libur nasional, dan tidak mau mengganti jam perkuliahan. Bila memperhatikan jurnal mengajar (dalam lampiran), rata-rata kehadiran dosen dalam mengajar adalah 10 kali pertemuan, dan (3) Dosen pada kampus $C$ dalam mengajar berdasarkan pengalaman seperti pada semester/tahun sebelumnya, sehingga Rencana Pelaksanaan Pembelajaran (RPP) atau Rencana Perkuliahan Semester (RPS) secara tertulis tidak begitu diperhatikan. Hal ini terbukti, peneliti minta ke Kajur atau Kaprodi selalu beralasan belum jadi/dicetak. Meskipun dalam kondisi seperti ini, kehadiran dosen dalam mengajar matakuliah Desain Komunikasi Visual bisa dikatakan baik, yaitu ratarata 12 kali pertemuan.

\section{Pendapat Dosen Pengampu Matakuliah Desain Komunikasi Visual}

Tanggapan dosen pengampu matakuliah Desain Komunikasi Visual di tiga perguruan tinggi terhadap RPP/RPS. Data diperoleh dari sampel di tiga perguruan tinggi, masingmasing 2 orang sebagai data bandingan yang diperoleh dari mahaisswa. Data tentang RPS/RPP yang diserahlan kepada mahasiswa di awal semester, dosen A1 menyatakan "ya", yang diberikan pada saat pertemuan perkuliahan pertama, dan dosen A2 di serahkan pada pertemuan ke dua, karena awal masuk harus diterangkan ruang lingkup materi, sekaligus kontrak perkuliahan khususnya tugas-tugas yang harus diselesaikan mahasiswa. Dosen B1 menyatakan "ya", seperti dalam silabus yang telah dibuat dalam lokakarya Jurusan Deskomvis, dan dosen B2 menyatakan "pada dasarnya saya menerangkan sesuai dengan silabus dan RPP/RPS yang telah saya susun". Dosen C1, menyatakan bahwa di awal perluliahan dijelaskan secara rinci, apa materi ruang lingkup Deskomvis. Mahasiswa mendengarkan dan menulis sendiri-sendiri apa kira-kira materi yang akan diberikan. Dosen C2 menyatakan bahwa RPP/RPS dijelaskan, mahasiswa yang menulis sendiri.

Cara mengajar bapak/ibu dosen yang mengajar matakuliah Desain Komunikasi Visual, antara lain, Dosen A1 biasa menggunakan ceramah, permodelan, konsultatif, refleksi (evaluasi), visualisasi (terstruktur), dosen A2 berpendapat bahwa matakuliah deskomvis merupakan matakuliah praktek, maka dalam mengajar sering menggunakan ceramah, demo, permodelan, penggalian ide kreatif, konsultatif, refleksi (evaluasi), dan visualisasi (terstruktur). Dosen B1 dan B2 di perguruan yang beda menyatakan bahwa 
dalam menerapkan metode ceramah, diskusi, tanya jawab, presentasi, riset visual, dan riset lapangan. Metode pengajaran ini hampir sama dengan di perguruan tinggi lain seperti C1 dan C2 menerapkan ceramah, demo, permodelan, penggalian ide kreatif, dan konsultatif. Agar dalam mengajar lebih komunikatif maka perlu adanya buku ajar.

Hingga saai ini belum ada buku ajar atau sejenisnya yang bisa mendukung perkuliahan matakuliah Desain Komunikasi Visual I hingga Desain Komunikasi Visual V. Apakah perlu diwujudkan?. Jawaban antara lain; dosen A1 menyatakan perlu, biar ada gambaran tentang Desain Komunikasi Visual secara teoritis maupun prakteknya, begitu juga dosen A2 menyatakan sangat perlu, karena buku yang dijual dipasaran itu kebanyakan teori umum tentang Desain Grafis, belum mengarah ke Desain Komunikasi Visual yang sesungguhnya. Dosen B1 menyatakan bagus bila itu terlaksana, karena membantu dosen dan mahasiswa untuk menyatukan persepsi tentang Desain Komunikasi Visual. Dosen B2 juga menyatakan perlu, karena adanya bacaan (buku) memudahkan mahasiswa dan dosen untuk memahami matakuliah Desain Komunikasi Visual. Kalau buku ini benar-benar ada, mahasiswa tidak selalu menunggu dan bertanya pada dosen pengampu matakuliah Desain Komunikasi Visual. Dosen C1 perguruan lain menyatakan bahwa pembuatn buku ajar merupakan ide yangbagus, namun dalam buku itu harus berisi semua hal dari Desain Komunikasi Visual I hingga Desain Komunikasi Visual V. Dosen C1 mengingatkan bahwa buku yang disusun harus mudah terbaca dan dipahami oleh mahasiswa, karena buku ini sifatnya penuntun mahasiswa untuk menyelesaikan matakuliah Desain Komunikasi Visual.

\section{Nilai pada Matakuliah Desain Komunikasi Visual}

Nilai yang diperoleh mahasiswa pada matakuliah Desain Komunikasi Visual di tiga perguruan tinggi Universitas Negeri Malang, Universitas Sebelas Maret Surakarta, dan Insitut Seni Indonesia Yogyakarta, rata-rata yang mendapat nilai (A) -- (A-): 24,6 mhs, $(B+)$-- (B-): 49,6 mhs, (C+) -- (C): 9,9 mhs, (D) -- (T): 15,9 mhs. Data lebih lengkap seperti tabel di bawah.

Tabel 1. Daftar Nilai Mk. Desain Komunikasi Visual I Di Tiga Perguruan Tinggi

\begin{tabular}{|c|c|c|c|c|c|c|c|c|c|c|c|c|c|c|}
\hline \multirow[b]{2}{*}{ NO } & \multirow{2}{*}{$\begin{array}{c}\text { PERGURUAN } \\
\text { TINGGI }\end{array}$} & \multirow{2}{*}{$\begin{array}{c}\text { OFF/ } \\
\text { KLS } \\
\end{array}$} & \multirow{2}{*}{$\begin{array}{l}\text { JLH } \\
\text { MHS } \\
\end{array}$} & \multicolumn{10}{|c|}{ JLH NILAI/KELAS } & \multirow[b]{2}{*}{ KET } \\
\hline & & & & A & A- & $\mathrm{B}+$ & $\mathrm{B}$ & $B-$ & $\mathrm{C}+$ & C & $\mathrm{D}$ & $\mathrm{E}$ & T/KSG & \\
\hline \multirow[t]{3}{*}{1} & \multirow[t]{3}{*}{$\begin{array}{l}\text { Univ. Negeri } \\
\text { Malang }\end{array}$} & $\mathrm{C}$ & 42 & 2 & 3 & 4 & 9 & 7 & 4 & 2 & 0 & 0 & 11 & \\
\hline & & D1 & 31 & 3 & 2 & 3 & 9 & 9 & 4 & 0 & 0 & 0 & 1 & \\
\hline & & D2 & 22 & 0 & 0 & 0 & 2 & 8 & 4 & 1 & 0 & 0 & 7 & \\
\hline 2 & UNS Surakarta & $\mathrm{R}$ & 41 & 2 & 0 & 0 & 29 & 0 & 0 & 5 & 0 & 5 & 0 & \\
\hline 3 & ISI Yogyakarta & $\mathrm{R}$ & 59 & 8 & 7 & 1 & 23 & 8 & 0 & 3 & 2 & 3 & 4 & \\
\hline \multicolumn{3}{|c|}{ JUMLAH } & 195 & 15 & 12 & 8 & 72 & 32 & 12 & 11 & 2 & 8 & 23 & \\
\hline
\end{tabular}


Tabel 2. Daftar Nilai Mk. Desain Komunikasi Visual II Di Tiga Perguruan Tinggi

\begin{tabular}{|c|c|c|c|c|c|c|c|c|c|c|c|c|c|c|}
\hline \multirow[b]{2}{*}{ NO } & \multirow[b]{2}{*}{ PERGURUAN TINGGI } & \multirow{2}{*}{$\begin{array}{c}\text { OFF/ } \\
\text { KLS }\end{array}$} & \multirow{2}{*}{$\begin{array}{l}\text { JLH } \\
\text { MHS }\end{array}$} & \multicolumn{10}{|c|}{ JLH NILAI/KELAS } & \multirow[b]{2}{*}{ KET } \\
\hline & & & & $A$ & A- & $\mathrm{B}+$ & $\mathrm{B}$ & B- & $\mathrm{C}+$ & $\mathrm{C}$ & $\mathrm{D}$ & $E$ & T/KSG & \\
\hline \multirow[t]{3}{*}{1} & \multirow[t]{3}{*}{ Univ. Negeri Malang } & $\mathrm{C3}$ & 44 & 1 & 3 & 7 & 6 & 11 & 3 & 0 & 4 & 9 & 0 & \\
\hline & & C4.1 & 29 & 0 & 6 & 5 & 2 & 1 & 6 & 2 & 1 & 6 & 0 & \\
\hline & & C4.2 & 22 & 0 & 4 & 6 & 3 & 2 & 0 & 4 & 2 & 1 & 0 & \\
\hline 2 & UNS Surakarta & $\mathrm{R}$ & 44 & 3 & 0 & 0 & 36 & 0 & 0 & 1 & 0 & 4 & 0 & \\
\hline \multirow[t]{2}{*}{3} & \multirow[t]{2}{*}{ ISI Yogyakarta } & $\mathrm{R}$ & 41 & 1 & 15 & 11 & 3 & 7 & 1 & 0 & 3 & 0 & 0 & \\
\hline & & $\mathrm{NR}$ & 18 & 6 & 0 & 0 & 11 & 0 & 0 & 1 & 0 & 0 & 0 & \\
\hline & JUMLAH & & 198 & 11 & 28 & 29 & 61 & 21 & 10 & 8 & 10 & 20 & 0 & \\
\hline
\end{tabular}

Tabel 3. Daftar Nilai Mk. Desain Komunikasi Visual III Di Tiga Perguruan Tinggi

\begin{tabular}{|c|c|c|c|c|c|c|c|c|c|c|c|c|c|c|}
\hline \multirow[b]{2}{*}{ NO } & \multirow[b]{2}{*}{ PERGURUAN TINGGI } & \multirow{2}{*}{$\begin{array}{c}\text { OFF/ } \\
\text { KLS }\end{array}$} & \multirow{2}{*}{$\begin{array}{l}\text { JLH } \\
\text { MHS }\end{array}$} & \multicolumn{10}{|c|}{ JLH NILAI/KELAS } & \multirow[b]{2}{*}{ KET } \\
\hline & & & & $A$ & A- & $\mathrm{B}+$ & $\mathrm{B}$ & $\mathrm{B}-$ & $\mathrm{C}+$ & $\mathrm{C}$ & $\mathrm{D}$ & $E$ & T/KSG & \\
\hline \multirow{3}{*}{1} & \multirow{3}{*}{ Univ. Negeri Malang } & C & 37 & 2 & 9 & 6 & 3 & 2 & 0 & 3 & 12 & 0 & 0 & \\
\hline & & D1 & 28 & 0 & 1 & 2 & 6 & 6 & 2 & 7 & 0 & 1 & 3 & \\
\hline & & D2 & 32 & 0 & 1 & 5 & 5 & 6 & 3 & 4 & 7 & 1 & 1 & \\
\hline 2 & UNS Surakarta & $\mathrm{R}$ & 37 & 7 & 0 & 0 & 24 & 0 & 0 & 3 & 0 & 2 & 1 & \\
\hline 3 & ISI Yogyakarta & $\mathrm{R}$ & 61 & 32 & 0 & 0 & 22 & 0 & 0 & 4 & 0 & 3 & 0 & \\
\hline \multicolumn{3}{|c|}{ JUMLAH } & 195 & 41 & 11 & 13 & 60 & 14 & 5 & 21 & 19 & 7 & 4 & \\
\hline
\end{tabular}

Tabel 4. Daftar Nilai Mk. Desain Komunikasi Visual IV Di Tiga Perguruan Tinggi

\begin{tabular}{|c|c|c|c|c|c|c|c|c|c|c|c|c|c|c|}
\hline \multirow[b]{2}{*}{ NO } & \multirow[b]{2}{*}{ PERGURUAN TINGGI } & \multirow{2}{*}{$\begin{array}{c}\text { OFF/ } \\
\text { KLS }\end{array}$} & \multirow{2}{*}{$\begin{array}{l}\mathrm{JLH} \\
\mathrm{MHS}\end{array}$} & \multicolumn{10}{|c|}{ JLH NILAI/KELAS } & \multirow[b]{2}{*}{ KET } \\
\hline & & & & $\mathrm{A}$ & A- & $\mathrm{B}+$ & $\mathrm{B}$ & $\mathrm{B}-$ & $\mathrm{C}+$ & $\mathrm{C}$ & $\mathrm{D}$ & $\mathrm{E}$ & $\mathrm{T} / \mathrm{KSG}$ & \\
\hline \multirow{3}{*}{1} & \multirow{3}{*}{ Univ. Negeri Malang } & C3 & 32 & 4 & 10 & 12 & 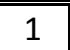 & 0 & 0 & 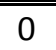 & 3 & 2 & 0 & \\
\hline & & C4.1 & 34 & 0 & 8 & 11 & 6 & 6 & 0 & 0 & 3 & 0 & 0 & \\
\hline & & C4.2 & 25 & 0 & 3 & 7 & 11 & 1 & 0 & 0 & 1 & 2 & 0 & \\
\hline 2 & UNS Surakarta & $\mathrm{R}$ & 35 & 4 & 0 & 0 & 13 & 0 & 0 & 15 & 0 & 3 & 0 & \\
\hline 3 & ISI Yogyakarta & $\mathrm{R}$ & 58 & 36 & 0 & 0 & 15 & 0 & 0 & 0 & 1 & 2 & 4 & \\
\hline \multicolumn{3}{|c|}{ JUMLAH } & 184 & 44 & 21 & 30 & 46 & 7 & 0 & 15 & 8 & 9 & 4 & \\
\hline
\end{tabular}

Tabel 5. Daftar Nilai Mk. Desain Komunikasi Visual V Di Tiga Perguruan Tinggi

\begin{tabular}{|c|c|c|c|c|c|c|c|c|c|c|c|c|c|c|}
\hline \multirow[b]{2}{*}{ NO } & \multirow[b]{2}{*}{ PERGURUAN TINGGI } & \multirow{2}{*}{$\begin{array}{c}\text { OFF/ } \\
\text { KLS }\end{array}$} & \multirow{2}{*}{$\begin{array}{c}\text { JLH } \\
\text { MHS }\end{array}$} & \multicolumn{10}{|c|}{ JLH NILAI/KELAS } & \multirow[b]{2}{*}{ KET } \\
\hline & & & & $\mathrm{A}$ & A- & $\mathrm{B}+$ & $B$ & B- & $\mathrm{C}+$ & $\mathrm{C}$ & $\mathrm{D}$ & $\mathrm{E}$ & $\mathrm{T} / \mathrm{KSG}$ & \\
\hline \multirow{3}{*}{1} & \multirow{3}{*}{ Univ. Negeri Malang } & $\mathrm{C}$ & 34 & 8 & "5 & (26 & 5 & 2 & 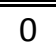 & 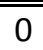 & 6 & 2 & 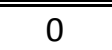 & \\
\hline & & $\mathrm{C} 3$ & 9 & 0 & 0 & 1 & 1 & 1 & 0 & 0 & 2 & 4 & 0 & \\
\hline & & $\mathrm{D}$ & 47 & 2 & 6 & 8 & 14 & 7 & 1 & 2 & 5 & 2 & 0 & \\
\hline 2 & UNS Surakarta & & & & & & & & & & & & & $\begin{array}{l}\text { dkv V } \\
\text { tdk } \\
\text { ada }\end{array}$ \\
\hline 3 & ISI Yogyakarta & $\mathrm{R}$ & 31 & 12 & 0 & 0 & 9 & 0 & 0 & 6 & 2 & 0 & 2 & \\
\hline & JUMLAH & & 121 & 22 & 11 & 15 & 29 & 10 & 1 & 8 & 15 & 8 & 2 & \\
\hline
\end{tabular}




\section{PEMBAHASAN}

Pembahasan dalam penulisan ini bertolak dari variable penelitian kemudian disimpulkan sesuai dengan tujuan penelitian. Analisa data yang digunakan deskriptif kualitatif merupakan rancangan yang dikembangkan dari kategori-ketegori yang ditemukan dan hubungan-hubungan yang disarankan atau muncul dari data. Berbagai data yang terkumpul yang terdiri dari cacatan lapangan, literature, dan dokumentasi yang diatur, diurutkan, dikelompokan berdasarkan kategori suatu uraian tertentu.

Dalam paparan ditulis secara uraian berdasarkan kategori suatu permasalahan yang diteliti. Data yang masuk dari berbagai sumber, baik dari mahasiswa, dosen pengampu, dokumen yang ada di Program Studi/Jurusan Desain Komunikasi Visual di salah satu Perguruan Tinggi di Jawa Timur, Perguruan Tinggi di Jawa Tengah dan Perguruan Tinggi di Yogyakarta. Penggabungan data ini dimaksudkan saling mengisi dan menguatkan data yang masuk untuk dipaparkan secara rinci dan jelas.

\section{Mahasiswa yang Lulus Tidak Tepat Waktu}

Tidak tepat waktu mahasiswa dalam studi di Desain Komunikasi Visual, dikarenakan mahasiswa sering menerapkan dua konsentrasi yaitu kuliah sambil bekerja. Adanya bekerja untuk mencari tambahan dana untuk mengerjakan tugas yang membutuhkan biaya yang tidak sedikit. Kerja diluar kampus sangat mengganggu kelancaran studi khususnya dalam menyelesaikan studinya, karena di tempat kerja mereka dituntut oleh death line untuk menyelesaikan karya. Di samping itu, mereka tentunya sudah merasakan enaknya mendapatkan gaji, sehingga kuliah yang seharusnya menjadi tanggung jawab utama terabaikan.

Mahasiswa tidak bisa mengatur waktu dengan tepat, bagaimana waktunya kuliah, bagaimana mengerjakan tugas, dan bagaimana mengatur waktu bekerja di luar kampus. Terlenanya bekerja paruh waktu di perusahaan kadang lupa wajib utama yang harus dijalankan, yaitu kuliah. Mengumpulkan tugas akhir semester yang sekedar memenuhi persyaratan ujian, ini merupakan hal yang biasa dilakukan mahasiswa tanpa memperhatikan kulitas tugas yang dikumpulkan. Pada akhirnya, nilai matakuliah Desain Komunikasi Visual tidak baik atau malah tidak lulus. Semua ini dikarenakan belum bisa mengatur waktu dengan baik dan teratur.

Kurang pahamnya menangkap materi yang diajarkan dosen, karena kurang adanya contoh-contoh karya Desain Komunikasi Visual yang baik, juga mempengaruhi semangat berkarya pada diri mahasiswa. Kurang pahamnya mahasiswa juga menyebabkan mahasiswa selalu menunggu perintah dari dosen untuk mengerjakan tugas, atau menunggu deadline waktu mengumpulkan tugas matakuliah Desain Komunikasi Visual.

Bila diperhatikan daftar nilai pada akhir semester menunjukkan sulitnya mahasiswa untuk mencapai nilai tertinggi " $A$ ", kebanyakan mahasiswa mendapat nilai " $B$ ". Bagaimana ini bisa terjadi apakah memang mahasiswanya tidak bisa mengerjakan seluruh perintah/tugas dosen, atau memang dosennya terlalu pelit memberi nilai. Ada 
beberapa mahasiswa yang tidak lulus atau hanya mendapat nilai " $C$ " yang disebabkan kurang seriusnya dalam mengerjakan tugas fortofolio akhir semester. Kelompok mahasiswa inilah akan akan memprogram kembali pada semester berikutnya pada matakuliah yang sama. Bila ini terjadi terus-menerus tentunya akan mengakibatkan mahasiswa lulus tidak bisa tepat waktu.

\section{Rendahnya Motivasi Mahasiswa dalam Memprogram Matakuliah Desain Komunikasi Visual}

Dosen sering tidak hadir dalam perkuliahan yang telah dijadwalkan, mengakibatkan mahasiswa tidak mau belajar di dalam kelas. Bila jam kosong, mereka hanya ngobrol atau bercanda dengan temannya sampai waktu jam perkuliahan selesai. Bila kondisi ini terus terjadi akan mempengaruhi psikologi mahasiswa yang menyebabkan motivasi belajar turun. Pada suatu saat, mereka selalu menganggap pada jam perkuliaan dosennya tidak hadir sehingga mahasiswa tersebut tidak masuk kuliah, padahal dosennya pada waktu itu hadir untuk menjelaskan tentang perkuliahan yang diampunya.

Mahasiswa kadang resah dan gundah, bila dosen yang dicarinya tidak ada di tempat. Maksud mahasiswa ingin cepat menyelesaikan tigas yang diberikan dosen pengampu, ternya kandas karena dosen yang dicari tidak ada di kantor. Kondisi ini kadang terjadi seperti di salah satu perguruan tinggi yang diteliti sampai rektornya turun tangan memanggil dosen yang jarang ada di kampus tersebut.

Dalam perguruan tinggi kadang dalam mengajar dibuat team dengan dosen lain, biasanya dosen senior dan yunior seperti pada matakuliah Desain Komunikasi Visual. Dalam mengajarnya team teaching tersebut kadang dipisah, dosen senior pada waktu tertentu, sedangkan yunior pada waktu yang beda. Kondisi ini kadang dalam menjelaskan materi perkuliahan tidak sama persepsinya, sehingga mengakibatkan mahasiswa menjadi binggung akan mengacu pada dosen yang mana. Bila ini terjadi akan mempengaruhi gairah dan motifasi belajar mahasiswa.

Ada dua perguruan tinggi yang belum menyampaikan deskripsi matakuliah melalui katalog atau pedoman pendidikan yang diterbitkan di Jurusan atau Fakultas masingmasing. Bila deskripsi matakuliah tertulis di dalam katalog atau pedoman pendidikan akan memudahkan mahasiswa untuk belajar atau mahasiswa bisa mengangkap sebagian materi dalam suatu matakuliah tertentu. Adanya kejelasan ini secara tidak langsung bisa untuk memotivasi mahasiswa dalam belajar.

Ada dosen dalam mengajarnya "spontanitas", maksudnya tidak terjadwal secara terstruktur, karena tidak ada Rencana Pelaksanaan Pembelajaran (RPP) atau Rencana Perkuliahan Semester (RPS). Padahal RPP/RPS adalah garis besar materi yang akan diajarkan dalam kurun satu semester. Bila ada RPP/RPS akan memudahkan dosen untuk mengajar khususnya team teaching, begitu juga mahasiswa yang selalu siap karena telah membaca RPP/RPS. 
Dosen yang baik adalah dosen yang memberi pelayanan sesungguhnya kepada mahasiswa yang membutuhkannya. Seperti dosen pengajar praktek, sebaiknya ada jadwal lain di luar jam mengajar untuk melayani konsultasi para mahasiswa yang ingin konsultasi tugas. Bila program ini berjalan, motovasi belajar mahasiswa akan meningkat yang tentunya kualitasnya juga meningkat.

\section{Mahasiswa Kurang Lancar dalam Mengikuti Matakuliah Desain Komunikasi Visual}

Kurang lancarnya mahasiswa untuk mengikuti perkuliahan, salah satunya dikarenakan mahasiswa belum paham isi materi perkuliahan. Bila mahasiswa sudah mengetahui tentunya tidak akan kesulitan, seperti pada pertemuan tertentu mereka harus sudah mendapatkan data survey lapangan sebagai dasar dalam membuat karya Desain Komunikasi Visual. Sebaliknya, bila mahasiswa tidak tahu materinya tenta mahasiswa tersebut tidah bisa mengerjakan tugas di dalam kampus, yang akhirnya mahasiswa tersebut hanya diam.

Bila ada acuan yang jelas, dosen dalam mengajarnya runtun dan enak, yang dampaknya mahasiswa senang mendengarkan materi yang disampaikan dosen pengampu. Akan lebih baik pedoman atau acuan juga diberitahukan kepada mahasiswa, sehingga mereka sudah siap mengerjakan tugas apapun yang diberikan dosen. Acuan atau pedoman yang dimaksud adalah silabus matakuliah yang secara detail menjelaskan isi dan kisi-kisi materi perkuliahan khususnya Desain Komunikasi Visual yang akan dikerjakan/dilaksanakan baik dosen maupun mahasiswa dalam kurun waktu satu semester.

\section{Perlunya Buku Ajar Sebagai Pendukung Materi Matakuliah Desain Komunikasi Visual}

Sampai saat ini belum ada buku yang membahas secara khusus tentang matakuliah Desain Komunikasi Visual, dari pra desain, desain, dan pasca desain, serta konsepnya. Buku ini berupa buku ajar sebagai pendukung atau pengantar mahasiswa dalam menempuh matakuliah Desain Komunikasi Visual. Buku yang sifatnya fleksibel, maksudnya bisa digunakan untuk matakuliah Desain Komunikasi Visual I hingga $\mathrm{V}$ pada Program Studi/Jurusan Desain Komunikasi Visual di perguruan tinggi se Indonesia.

Buku ajar tersebut merupakan solusi persoalah yang terangkat pada penelitian ini, yaitu agar mahasiswa lancar dan sukses dalam belajar di perguruan tinggi. Maka dari itu isi materi dan bobot buku ajar harus sama dengan matakuliah Desain Komunikasi Visual I hingga V. Buku berjudul "Desain Komunikasi Visual, Statis dan Dinamis" (seperti gambar di bawah) yang ditujukan untuk reverensi matakuliah Desain Komunikasi Visual I s.d V, maka penulis menyajikan dua kelompok besar yaitu:

a) Teori, yang terdiri; strategi pemasaran dan media komunikasi, penekanan pesan dalam media komunikasi, kreativitas dalam mendesain, positioning, analisis perusahaan, produk dan konsumen, dan elemen desain komunikasi visual.

b) Praktek, meliputi; estetika desain kemasan, corporate identity, perancangan layout, perencanaan media, county profile, menggambar karakter, perancangan storyboard, dan perancangan animasi. 


\section{SIMPULAN DAN SARAN}

Penelitian ini membahas tentang matakuliah wajib Desain Komunikasi Visual di Perguruan Tinggi mantan IKIP di Jawa Timur, Perguruan Tinggi (Universitas) di Jawa Tengah dan Perguruan Tinggi Seni di Yogyakarta. Penelitian ini merupakan penelitian tahap pertama yang meneliti permasalahan mahasiswa dalam proses pembelajaran, khususnya matakuliah wajib bersyarat, yaitu Desain Komunikasi Visual I, II, III, IV, dan V. Dalam penelitian ini diketahui adanya kurang kepahaman mahasiswa terhadap materi yang diajarkan dosen. Media berupa buku ajar Desain Komunikasi Visual merupakan salah satu solusi belajar dan pendalaman terhadap materi yang diajarkan. Adanya buku Desain Komunikasi Visual, mahasiswa diharapkan bisa mandiri dan dapat meningkatkan hasil studinya. Adanya buku ajar Desain Komunikasi Visual permasalahan yang ditemui di lapangan seperti di bawah seperti; tidak tepat waktu, kurang motifasi, kurang lancar dalam studinya, dan belum adanya buku ajar ajar untuk matakuliah Desain Komunikasi Visual.

1. Tidak tepat waktu mahasiswa dalam studi di Desain Komunikasi Visual, dikarenakan mahasiswa sering menerapkan dua konsentrasi yaitu kuliah sambil bekerja. Mahasiswa juga belum bisa mengatur waktu antara kuliah dengan bekerja Pada akhirnya, nilai matakuliah Desain Komunikasi Visual tidak baik atau malah tidak lulus, karena mereka belum bisa mengatur waktu dengan baik dan teratur. Ada beberapa mahasiswa yang tidak lulus atau mendapat nilai "C" yang disebabkan kurang seriusnya dalam mengerjakan tugas. Mahasiswa ini tentu akan akan memprogram kembali pada semester berikutnya, yang mengakibatkan mahasiswa lulus tidak bisa tepat waktu.

2. Mahasiswa kurang adanya motivasi dalam memprogram matakuliah Desain Komunikasi Visual disebabkan oleh dosen sering tidak hadir dalam perkuliahan, mengakibatkan mahasiswa tidak mau belajar di dalam kelas. Begitu juga dosen yang dicari tidak ada di kampus yang membuat resah dan gundah, mahasiswa ingin cepat menyelesaikan tugas yang diberikan dosen pengampu. Kurang persamaanya persepsi dalam meyampaikan materi dalam team teaching anatara dosen senior dengan dosen yunior. Kondisi tersebut karena belum adanya Rencana Pelaksanaan Pembelajaran (RPP) atau Rencana Perkuliahan Semester(RPS) sebagai acuan dalam belajar pembelajaran matakuliah Desain Komunikasi Visual.

3. Mahasiswa kurang lancar dalam mengikuti matakuliah Desain Komunikasi Visual, disebabkan mahasiswa belum paham isi materi perkuliahan karena acuan dosen pengampu matakuliah Desain Komunikasi Visual belum ada. Maka pedoman harus direalisasikan seperti silabus matakuliah yang secara detail menjelaskan isi dan kisikisi materi perkuliahan khususnya Desain Komunikasi Visual yang akan dipakai sebagai rujukan dosen maupun mahasiswa dalam kurun waktu satu semester.

4. Sudah saatnya Program Studi Desain Komunikasi Visual mempunyai buku ajar untuk matakuliah berjenjang Desain Komunikasi Visual I hingga Desain Komunikasi Visual V. Buku ajar tersebut merupakan solusi perrcepatan studi, agar mahasiswa lancar dan sukses studinya. Isi materi dan bobot buku ajar harus sama dengan matakuliah Desain Komunikasi Visual I hingga V. Buku yang sifatnya fleksibel yang bisa digunakan untuk matakuliah Desain Komunikasi Visual I hingga $V$ pada Program Studi/Jurusan Desain Komunikasi Visual di perguruan tinggi se-Indonesia. 
Agar penelitian ini bermanfaat, maka diperlukan tindak lanjut dari permasalahan yang ditemukan. Dari hasil penelitian ini, maka penulis menyarankan berbagai pihak yang terkait.

1. Salah satu Perguruan Tinggi di Jawa Timur

Perlu segera dibuatkan silabus yang sesuai dengan perkembangan zaman, sehingga arah ke depan Program Studi Desain Komunikasi Visual lebih terarah jelas. Guna mendukung kelancaran perkuliahan Program Studi Desain Komunikasi Visual perlu adanya buku ajar sebagai pendamping perkuliahan.

2. Salah satu Perguruan Tinggi di Jawa Tengah

Dosen supaya dikurangi kegiatannya di luar kampus, agar mahasiswa bisa sering konsultasi tentang perkuiahan Desain Komunikasi Visual. Supaya mahasiswa lebih bisa mandiri perlu adanya buku ajar sebagai rujukan dalam mengatasi kebuntuan komunikasi antara dosen dengan mahasiswa.

3. Salah satu Perguruan Tinggi di Yogyakarta

Keadministrasian supaya lebih diperhatikan, seperti katalog/pedoman pendidikan, Rencana Pelaksanaan Pembelajaran (RPP) atau Rencana Perkuliahan Semester (RPS), silabus, maupun yang lain agar dalam mengajar lebih jelas. Meskipun di Yogyakarta sudah banyak dosen yang menulis buku, sebaiknya ke depan penulisan buku diarahkan pada matakuliah Desain Komunikasi Visual I hingga Desain Komunikasi Visual V.

Perlu digarisbawahi, bahwa penelitian ini merupakan penelitian tahap I (Pertama), yang hanya sampai pada tersusunnya draf buku ajar Desain Komunikasi Visual. Sementara ini permasalahan-permasalahan sudah dapat diketahui dan sudah ada solusinya yaitu tersedianya buku ajar yang berisi materi Desain Komunikasi Visual I, II, III, IV, dan V. Apakah buku ini sudah dapat siterima oleh mahasiswa dan dosen pengampu matakuliah sesuai dengan materi yang diajarkan, maka perlu penelitian lebih lanjut berupa ujicoba. Pada penelitian lanjutan (uji coba) nantinya diharapkan dapat memberi masukkan khususnya berbagai materi yang terkandung dalam buku ajar Desain Komunikasi Visual. Adanya masukkan-masukkan tersebut berarti bertambahnya kuantitas dan kualitas isi buku yang sesuai dengan materi pengajaran Desain Komunikasi Visual. 


\section{DAFTAR PUSTAKA}

Arsyat, Azhar. 2007. Media Pembelajaran. Jakarta: PT. Raja Grafindo Persada Beakley, George C. 1974. Design, Serving the Meeds of Man. USA: Macmillan Ltd.

Fakultas Sastra dan Seni. 2007. Pedoman Akademik. Surakarta: Universitas Sebelas Maret

ISI, 2006. Buku Petunjuk Pendidikan. Yogyakarta: Institut Seni Indonesia Yogyakarta Jurusan Seni dan Desain. 2007. Katalog Jurusan Seni dan Desain Fakultas Sastra. Malang: Universitas Negeri Malang

Kusrianto, Adi. 2007. Pengantar Desain Komunikasi Visual. Yogyakarta: Andi Rohani, Ahmad. 1997. Media Instruksional Edukatif. Jakarta: Rineka Cipta Safanayong, Yongky. 2006. Desain Komunikasi Visual Terpadu. Jakarta: Arte Intermedia Tinarbuko, Sumbo. 2007. Semiotika Analisis Tanda pada Karya Desain Komunikasi Visual. dalam Nirmana Vol 3 No.1. Surabaya: Universitas Petra 